\title{
Lectio praecursoria
}

\section{Vertaistukiryhmässä alkoholistien läheiset tukevat toisiaan - siis itseään}

\author{
Venla Kuuluvainen \\ puheviestinnän yliopistonlehtori, FT \\ Tampereen yliopisto \\ venla.kuuluvainen@uta.fi
}

\begin{abstract}
Lectio praecursoria puheviestinnän väitöskirjaksi tarkoitetun tutkimuksen Suppotive communication in Al-Anon mutual-aid groups tarkastustilaisuudessa Tampereella 17.6.2016. Vastaväittäjänä toimi tutkimusprofessori Marja Holmila (THL) ja kustoksena professori Pekka Isotalus (Tampereen yliopisto).
\end{abstract}

Alkoholin suurkulutus ja alkoholismi ovat jollakin tasolla kaikille meille suomalaisille tuttuja asioita. Vaikka alkoholismiin suhtaudutaan usein vain yksilöä itseään koskevana ongelmana, koskettaa se monesti myös useaa alkoholistin läheistä. Alkoholistien läheisten tiedetään kärsivän kriisiytyneen elämäntilanteen aiheuttamasta stressistä, joka puolestaan aiheuttaa monenlaista fyysistä ja psyykkistä oirehdintaa. Usein puhutaan läheisriippuvuudesta kun pyritään kuvailemaan erilaisista riippuvuuksista kärsivien läheisiä. Läheisriippuvuudella on viitattu monenlaisiin piirteisiin, joiden on ajateltu olevan tyypillisiä riippuvuuksista kärsivien läheisille.

Voi kuitenkin hyvällä syyllä kysyä, missä läheisten taakka tai haaste itseasiassa sijaitsee. Läheisten persoonallisuuden analysoinnin sijaan katse tulisikin kääntää siihen vuorovaikutussuhteeseen jossa läheisriippuvuudeksi kutsumaamme käyttäytymistä ilmenee. Väitöskirjassani olenkin lähestynyt läheisten tapaa olla suhteessa alkoholistin kanssa viestinnän tapoina ja kaavoina.

Ehkä osittain juuri tämän läheisten taakan paikantamisen vaikeuden takia, alkoholistien läheisiä on tutkittu yllättävän vähän ja usein siitä näkökulmasta, miten läheiset voisivat tukea alkoholistin raitistumista. Tässä tullaan toiseen usein havaitsemaani vinoutumaan alkoholistien läheisistä puhuttaessa. Koska läheisten oman taakan ajatellaan johtuvan alkoholistin juomisesta, ehdotetaan ratkaisuksi usein alkoholistin raitistumista. Tällöin läheisten roolina nähdään vain alkoholistin raittiuden tukeminen.

Vaikka alkoholistin raitistuminen saattaa parantaa ihmissuhdetta ja tutkimukset osoittavat että läheiset voivat olla suurena apuna tässä, 
alkoholismista on kuitenkin erittäin vaikea toipua ja saavutettu raittius saattaa olla lyhytkestoista. Läheiset tarvitsevatkin tukea oman hyvinvointinsa ylläpitämiseksi riippumatta läheisen juomisesta tai juomattomuudesta.

Väitöskirjassani olen tutkinut vertaistukiryhmien verkostoa nimeltä Al-Anon, joka pyrkii tarjoamaan alkoholistien läheisille tällaista tukea. Al-Anon on maailmanlaajuinen vertaistukiryhmien verkosto, joka perustettiin 1950-luvulla USA:ssa Anonyymien Alkoholistien rinnalle. Al-Anon perustuu 12-askeleen ohjelmalle kuten Anonyymit Alkoholistitkin. Al-Anon ryhmien ideologiaan kuuluu näkemys alkoholismista sairautena ja ryhmät keskittyvät läheisten oman toipumisen tukemiseen. Näin ollen ryhmissä jäsenet jakavat vain omia kokemuksiaan vuorotellen, ja toisten suora neuvominen on kiellettyä. Palaverit eivät siis muistuta vapaata keskustelua vaan noudattavat tietynlaista kaavaa.

Al-Anonin tarjoama tuen lähde on monelle alkoholistin läheiselle tärkeä, koska ulkopuolisten on usein vaikea ymmärtää läheisten kokemusmaailmaa. Väitöskirjani haastateltavat kertoivatkin usein ulkopuolisten vaikeudesta ymmärtää esimerkiksi sitä, miksi läheinen alkoholistin juomisen jatkumisesta huolimatta jää suhteeseen. Vertaistuki olikin tarjonnut väitöskirjani haastateltaville jatkuvasti saatavilla olevan tuen lähteen. Tärkeää oli ollut se, että ryhmässä jokaiselle annetaan oma aikansa edetä toipumisprosessissaan ja neuvoja suhteen jatkamisesta tai päättämisestä ei anneta.

Vertaistuki Al-Anonissa keskittyykin läheisten oman hyvinvoinnin parantamiseen. Lähestyn väitöskirjassani Al-Anonin vertaistukea supportiivisen viestinnän, eli sosiaalisen tuen viestinnän teoreettisen viitekehyksen kautta. Tässä viitekehyksessä väitöskirjani tarkoitus on tarkastella sitä, millaista tukea Al-Anon ryhmissä viestitään, mikä ryhmien tuessa on ollut jäsenille tärkeää, sekä millaisia lyhyt- ja pitkäaikaisseurauksia Al-Anonin tuella on ollut muun muassa suhteelle alkoholistin kanssa.

Vastatakseni näihin kysymyksiin havainnoin Al-Anon ryhmien viestintää, haastattelin ryhmien jäseniä sekä keräsin jäsenten vastauksia kyselylomakkeella. Nostan nyt esille muutamia väitöskirjani tärkeimpiä tuloksia.

Ryhmiä havainnoidessa pääsin näkemään sen, millaista tukea Al-Anonin palavereissa viestitään. Väitöskirjan tulosten mukaan ryhmissä viestitään emotionaalista tukea, joka tarkoittaa esimerkiksi ymmärryksen ja hyväksymisen ilmaisuja. Merkillepantavaa on kuitenkin se, että koska ryhmissä suora sanallinen toisten kokemusten kommentoiminen ei ollut sallittua, sanattomat tuen ilmaisut korostuivat. Tällaisia olivat esimerkiksi ymmärrystä ilmaisevat nyökkäykset, rohkaisevat hymyt ja kuuntelemista viestivät eteenpäin nojautumiset. Emotionaalisen tuen lisäksi jaetut kokemukset sisälsivät tietoa alkoholismista ja esimerkkejä mahdollisista tavoista toimia alkoholistin kanssa, eli tiedollista tukea. Suorien neuvojen sijasta tiedollinen tuki esitettiin kuitenkin ryhmissä epäsuorasti oman kokemuksen jakamisen muodossa. Sen sijaan siis, että sanottaisiin että sinun tulisi toimia tietyllä tavalla, jäsenet kertovat siitä mikä heitä itseään oli auttanut. Näiden tuen muotojen lisäksi ryhmissä esiintyi jäsenten itsetuntoa kohottavaa tukea kuten kehuja jäsenten nopeasta edistymisestä sekä yhteenkuuluvuuden ilmaisuja eli sosiaalisten verkostojen tukea.

Havainnointien jälkeen tehdyt jäsenten haastattelut lisäsivät jäsenten näkemyksen omiin havaintoihini Al-Anonin tuen viestinnästä. Haastatteluissa selvisi, että Al-Anonin sosiaalisessa tuessa jäsenille erityisen tärkeää on se, että 
tuki tulee nimenomaa vertaisilta, jolloin tuen antajan ja saajan roolit hämärtyivät ja jäsenten välinen tasa-arvo korostuu.

Onkin erityisen kiinnostavaa, että Al-Anonissa jäsenen jakama kokemus saattaa samanaikaisesti auttaa jäsentä itseään jäsentämään omaa tilannettaan, mutta toimia myös tukena muille. Haastateltavat esimerkiksi kertoivat, kuinka se, että puhuja oli kokenut jotakin järkyttävää, ja silti istui nyt ryhmässä kertomassa kokemuksestaan, joskus jopa hymyssä suin, antoi heille toivoa: ehkä omatkin vaikeat kokemukseni muuttuvat joskus avun lähteeksi muille. Ryhmien tuen viestiminen rakentuikin sellaisen käsityksen ympärille, jonka mukaan kyky tukea muita mahdollisimman hyvin on osoitus omasta toipumisesta.

Haastattelut paljastivat myös, että Al-Anon toimi paikkana, jossa se asia joka oli aikaisemmin eristänyt jäsenen muista, eli läheisen alkoholismi, olikin nyt se asia, joka yhdisti jäsenen muihin ihmisiin. Jäsenet kokivat myös tuen viestimisen nimenomaa omien kokemusten jakamisen muodossa tärkeäksi. Tällainen tuen viestimisen muoto kunnioittaa jokaisen jäsenen omaa toipumisprosessia eikä aseta paineita edistymiselle.

Yhtenä väitöskirjani tarkoituksena oli selvittää myös sitä, miten vertaistuki toimii. Miten supportiivinen viestintä Al-Anonissa saa erilaisia lyhyt-ja pitkäaikaisseurauksia jäsenten näkökulmasta aikaiseksi? Vastauksena näihin kysymyksiin tuloksista nousi esille kiinnostava havainto: tuen sanallisen sisällön lisäksi ryhmissä jäsenille oli tärkeää se, millaiseksi tuki sai heidät tuntemaan itsensä. Tällainen supportiivisen viestinnän suhdetaso viestittää muun ryhmän suhtautumisesta yksittäiseen jäseneen: millainen minä olen muiden silmissä? Esimerkiksi se, että kaikki ryhmäläiset puhuvat pala- vereissa yhtä kauan, rakentaa jäsenille kuvaa itsestä tasa-arvoisena ryhmän jäsenenä. Tällaisessa vuorovaikutuksessa myös ryhmään vasta tulleen puheenvuoro on yhtä tärkeä ryhmälle kuin ryhmässä jo vuosia käyneen puheenvuoro. Näin myös ryhmään juuri tulleen kokemukseen suhtaudutaan mahdollisena tuen lähteenä muille. Esimerkiksi eräälle jäsenelle kauemmin ryhmässä käyneen jäsenen, eli niin sanotun "konkarin", ehdotus palvelutehtäviin osallistumisesta oli ollut osoitus konkarin uskosta jäsenen kykyyn hoitaa kyseinen vastuutehtävä. Näin siis ehdotus palvelutehtävästä auttoi osaltaan rakentamaan uuden jäsenen käsitystä itsestään vastuuntuntoisena ja Al-Anonille tärkeänä yksilönä.

Kuten jo mainitsin, Al-Anonin tuen sisältämä tiedollinen puoli kuten esimerkit mahdollisista tavoista toimia alkoholistin kanssa, keskittyivät nimenomaa jäseniin itseensä. Haastateltavat kertoivat, että ryhmissä vain alkoholistin edesottamuksista puhumista pidettiin vasta-alkajan merkkinä. Kauemmin ryhmässä käyneet pyrkivätkin omalla esimerkillään ohjaamaan jäsenten fokusta jäseneen itseensä ja hänen omaan käyttäytymiseensä suhteessa alkoholistiin. Oleellista kuitenkin on se, että tämän viestinnän muuttamisen tarkoituksena ei ollut alkoholistin raitistaminen vaan jäsenten oma hyvinvointi ja elämän helpottaminen.

Tällaisten uusien toimintamallien lisäksi Al-Anonin supportiivinen viestintä oli antanut läheisille myös voimaa ja rohkeutta muuttaa käyttäytymistään. Ryhmä tarjosi jäsenille kuulumisen paikan, jossa tukea oli saatavilla tapahtui suhteessa mitä hyvänsä. Lisäksi ryhmä tarjosi paikan harjoitella vuorovaikutustaitoja. Eräs haastateltava kutsuikin ryhmää hänen "terveeksi perheekseen" alkoholismin sairastuttaman perheensä rinnalla. Haastateltavat kertoivat oppineinensa ryhmissä esimerkiksi 
kuuntelun taidon, jota hyödyntää myös suhteessa alkoholistin kanssa.

Haastateltavat kertoivatkin Al-Anonin tuen auttaneen heitä muuttamaan omaa viestintäänsä suhteessa alkoholistiin. Jäsenet kertoivat pyrkineensä muun muassa asettamaan rajoja ja ottamaan tilaa suhteessa. Yksi haastateltava esimerkiksi kertoi että se, että hän oli osallistunut tähän tutkimukseen ja kertonut siitä myös alkoholistipuolisolleen, oli esimerkki omien rajojen piirtämisestä.

Se, että haastateltavat olivat kyenneet muuttamaan omaa viestintäänsä oli osalla parantanut suhteen viestintäilmapiiriä kokonaisuudessaan ja muuttanut suhteen läheisemmäksi. Toisaalta, osa kertoi myös entistä voimakkaammasta välien kylmenemisestä tai jopa suhteen päättymisestä eroon. Kaikille haastatelluille oli kuitenkin yhteistä se, että oma päänsisäinen käsitys suhteen tilasta sekä omista mahdollisuuksista siinä, oli Al-Anonin tuen avulla selkeämpi.

Näissä väitöskirjani tuloksissa on kaksi erityisen huomionarvoista asiaan. Ensimmäinen on se, että paras tuki ei aina ole ilmeistä ja suoraa, sellaista jossa tuen antaja ja tuen saaja ovat tarkasti selvillä. Sen sijaan on tilanteita, joissa tärkeämpää on se, että vuorovaikutuksen osapuolet voivat erilaisista elämänkokemuksista huolimatta kohdata sellaisella universaalilla ihmisyyden tasolla, jossa oleellista on ihmettely ja ymmärtämään pyrkiminen. Näin tuen antaja ei asetu tietäjän asemaan, vaan kanssakulkijaksi ja kuuntelijaksi. Tällainen tuki on kohteliasta ja kunnioittaa tukea tarvitsevan itsemääräämisoikeutta.

Tällainen vuorovaikutus tulee itseasiassa ylipäätään määritellyksi tueksi vain epäsuorasti esimerkiksi sen tilanteen kautta missä tukea antava keskustelu käydään. Al-Anonin kohdalla voisi siis itseasiassa sanoa, että monologimainen jäsenen jakama kokemus tulee määritellyksi tueksi vain siksi, että se jaetaan nimenomaa vertaistukiryhmässä ja vuorovaikutuksessa toisten kertomien kokemusten kanssa. Tällainen supportiivinen viestintä ei siis ole eriteltävissä yksittäisiin viesteihin, vaan saa merkityksensä vuorovaikutuksessa. Supportiivisessa vuorovaikutuksessa nimellinen tuen saaja voikin kokea itsensä voimattoman uhrin asemasta aktiivisesti omaa tilannettaan jäsentäväksi ja siitä vastuuta ottavaksi toimijaksi. Tähän voi riittää jo kokemus sen arvokkuudesta, että uskaltaa puhua kokemuksistaan.

Toinen tuloksista nouseva erityisen huomionarvoisa asia on se, miten tukea antava viestintä Al-Anonissa ikään kuin säteili viestintäsuhteeseen alkoholistin kanssa. Tulos kertoo siitä, miten läheisissä ihmissuhteissa ilmeneviä ongelmia voi itseasiassa pyrkiä ratkomaan myös suhteen ulkopuolella. Toisin sanoen, tilanteissa, joissa läheisen ihmissuhteen korjaamista ei kyetä aloittamaan suhteen sisällä, supportiivinen viestintä toisaalla saattaa auttaa purkamaan tilannetta.

Tähän kuitenkin tarvitaan nimenomaa viestintää muiden kanssa. Tutkimukseni haastateltavista useat painottivatkin nimenomaa ryhmissä säännöllisesti käymisen ja ihmisten tapaamisen tärkeyttä, vaikka Al-Anonilla on olemassa myös kirjallisuutta ja erilaisia oppaita. Tulkitsen tämän liittyvän jo aiemmin mainitsemaani ryhmien suhdetason tärkeyteen. Vaikka jäsenet jakavat ryhmissä tietoa esimerkiksi alkoholismista, tärkeintä muutoksen kannalta on se, että ryhmä mahdollistaa jäsenten identiteetin uudelleenrakentumisen. Tässä toiset ihmiset ryhmässä toimivat peileinä, jotka heijastavat kuvaa ryhmään kuuluvasta, tukiverkoston omaavasta ja itsestään huolehtivasta ihmisestä. 